\title{
Blended Learning: Impact on Student Motivation and Understanding
}

\author{
Inda Mustika Permata ${ }^{1, *}$ Bima Jon Nanda ${ }^{1}$
}

\author{
${ }^{1}$ International Relations Department, Social and Political Sciences Faculty, Universitas Andalas \\ *Corresponding author.Email: indamustikapermata@soc.unand.ac.id
}

\begin{abstract}
Blended learning is a combination of learning or a combination of face-to-face and online learning elements in a coherent manner. This method can be a solution to the impact of a pandemic on lectures. Therefore, this paper seeks to describe the impact of using the blended learning method on student motivation and understanding in lectures. Primary data applied in this paper to see students' perceptions regarding the learning methods applied and the obstacles they feel during lectures. The population is all participants in the International Law class, Department of International Relations, Universitas Andalas. This paper shows that blended learning can be a choice for lecturers that can increase student understanding and motivation in learning. The implementation of this method requires detailed lecture instructions so that students can focus on learning. This blended learning method depends on a stable internet connection network and a stable Learning Management System (LMS) server as a place for conducting online lectures. However, based on the survey, students had problems accessing the LMS because the servers were often down. This problem makes it difficult for students to carry out class activities that support the achievement of learning outcomes.
\end{abstract}

Keywords: Blended Learning, motivation, understanding, students

\section{INTRODUCTION}

For lecturers, learning is usually done face-to-face in class. However, the world transformation that has entered the era of industrial revolution 4.0 has made technology not only an essential part of today's life, but the use of the internet has become a necessity. Therefore, this phenomenon also affects the world of education, namely that lecturers are required to be more innovative and creative in carrying out lectures that combine technology in it. This innovation provides benefits for lecturers and students; namely, they can access from anywhere and anytime. Flexibility in the class is one of the advantages of this technological development. However, the use of technology in learning is still minimally applied.

The widespread of the coronavirus to various regions in the world also has an impact on the education sector. The learning process must be carried out online in order to break the chain of spreading the virus. Of course, this is a challenge for universities because online learning provides space for lecturers or students not maximally in carrying out lectures. The frequent challenges faced are lack of time, difficulty access, lack of resources, lack of expertise, and lack of support facilities [1]. Another challenge that must be faced is the application of the learning plan, which, of course, will be very different when the lecturer delivers it online compared to offline class. Then, the class dynamics that will be very different because of only virtual face-to- face. Interaction between lecturers and students is not interactive and lively. Class discussions will also be a challenge in itself because online classes will make interactions between students to conduct discussions quite limited. As a result, the learning outcomes have designed were not achieved. Therefore, this paper seeks to describe the impact of using the blended learning method on student motivation and understanding in lectures.

\section{LITERATURE REVIEW}

There have been many experts who discussed the use of the blended learning method in the learning process. According to Heinze and Scott, blended learning is a combination of learning or a combination of face-toface and online learning elements in an integrated 
manner [2]. Then Carman (2005) in his writing explains that in conducting blended learning five essential things must be considered so that the mixed learning process can run smoothly, first, live events, namely learning is carried out synchronously. Second, online content, where students can complete the learning stages via the internet. Third, collaboration, that is, there must be online discussions carried out by students in learning either with lecturers or with peer students. Fourth, assessment, which must have a tool to measure student understanding. Fifth, reference materials, namely lecturers providing online references that can be uploaded by students [3]. Carman's work clarifies the steps that must be prepared by lecturers in optimally applying the blended learning method in learning. Then, according to Curtis and Lawson (2001) that the interaction that occurs between students is a characteristic of success in asynchronous learning. This interaction can be done in-class activities such as group discussions [4].

The next article is from Harvey Singh (2003). According to him, the learning process and preferences of the instructors tend to vary from one another. Organizations (in this case, educational institutions such as universities) must use the blended learning approach as a strategy to create content in the right format at the right time. Blenden learning combines various designed media that are related. Blended learning programs can use a variety of lessons, such as virtual devices, websites. Blended learning combines various activities, including face-to-face meetings, elearning. Learning with this method sometimes uses synchronous or asynchronous models. According to Harvey Singh, initially, the blended learning method was often associated with traditional (face-to-face) learning with e- learning activities. However, according to Harvey Singh, there are many blended learning methods. This form does not only combine face-to-face learning and e-learning, such as Blending Offline and Online Learning, Blending Self- Paced and Live, Collaborative Learning, Blending Structured and Unstructured Learning, Blending Custom Content with Off-the-Shelf Content, Blending Learning, Practice, and Performance Support [5].

The writings of Harvey Singh not only show the blended learning method as an effective learning method in various situations, especially when facing a pandemic situation where the rules of maintaining distance will limit the interaction between students and instructors. However, Harvey Singh emphasized that Blended Learning cannot be understood thoroughly. Blended learning is not only a combination of two face-to-face and online learning methods, but it is more than that and takes various forms. However, it concluded that the blended learning method prioritizes the use of platforms that support online learning and the use of technology such as instant messaging applications, online conferences, discussion forums, computer-based training and assessment modules, and others. So that the application of Blended learning is very diverse, tailored to the needs and objectives.

Furthermore, from research conducted by Sudarman (2014) that the use of learning strategies using blended learning has more significant benefits for students learning face-to-face learning. In his research, Sudarman emphasized the importance of being able to combine face-to-face learning and learning optimally. Because, in its implementation, according to Sudarman, lecturers need to ensure that students can maintain learning activities or what is known as Self-Regulated Learning (SRL) [6]. Furthermore, Norah Jones, in her writing, emphasized that the application of the blended learning method can be a challenge for the university if they are not anticipating. There are three challenges described by Jones, such as technical problems related to information and communication technology (ICT), then learning and teaching problems related to curriculum development that is suitable for student needs.

Finally, on cultural issues, Jones is more focused on supporting campus management related to policies that can accommodate blended learning [7]. From the writings above, it shows that many experts have discussed Blended Learning, but no one has discussed how it relates to student motivation. Therefore, this paper focuses more on discussing the practice of blended learning and its impact on student understanding and motivation.

\section{METHODS}

In collecting data, this paper uses primary data. The aim is to see students' perceptions regarding the learning methods applied and the constraints they feel during lectures. The instrument used was a questionnaire with five Likert scales. The scale consists of five levels, namely "5" explains "strongly agree," while "4" illustrates "Agree," then "3" is "neutral," then "2" and "1" explains "disagree" and "strongly disagree." This scale is a measure of student opinion regarding the statement asked.

The population is all students participating in the International Law class, Department of International Relations, Universitas Andalas. Before being distributed, the questionnaire was reviewed by the lecturer team who taught the course. On his suggestion, the statement rewritten to ensure that the respondent could understand the statement wanted to perceive. The questionnaire was distributed via an online platform to International Law class students. After the data is collected, we analyzed the summary provided by the online questionnaire.

\section{RESULTS}

Lectures are carried out based on the outcome-based Semester Learning Plan (RPS) that has been designed. 
In the process, the video was about 30 minutes long. The video made not only contains an explanation from the instructor but is also supported by displaying a PowerPoint containing the main points in the material discussed. In addition to displaying powerpoints, videos have also been equipped with subtitles to make it easier for students to absorb the subject matter, so not only listening to the audio, but students can also read subtitles to understand better the material delivered - the addition of subtitles based on two other reasons. First, adding subtitles will help students understand the material if the material presented by the instructor in the video is not too explicit, caused if the instructor speaks too fast. The subtitle then has an essential role in summarizing what the instructor says in the video. So, the subtitles not only write down what the instructor or lecturer said but also become a reference for students to see what conclusions the instructor conveyed. Second, subtitles will help students from abroad. If their Indonesian is not too good, they can look for in the subtitles video so that the subtitles help these students.

After students watched the material, all activities centered on the i-learn class. The activities carried out include filling out the attendance list, taking quizzes, reading materials, and discussing with the group using the i-learn forum feature, submitting assignments, and filling out lecture questionnaires. The features in ilearn vary widely and help lecturers to carry out lectures online, with conditions like offline classes in general. Lecturers can apply discovery learning and small group discussion methods. This method can be provided by providing trigger questions for students regarding the topic studied. The aim is for students to maximize their understanding by discussing the question in their peer group.

The subject carried out is theoretical. So the lecture can be done in class. Therefore, the use of the blended learning method able to be applied in International Law classes. In general, these lectures run according to schedule each week. However, in particular, there are obstacles faced and can interfere with the course of the lecture process. The obstacles are related to student access to I-learn. International law class students have no difficulty using the features in I-learn. Signal and connection are problems that students often complain about. The Faculty (FISIP) I-Learn (LMS) Server is down frequently. Sometimes when students are working on a quiz, suddenly, the I-Learn connection disappears. So, the quiz is not done optimally, and the score is not good either. Often, when this happens, the lecturer has to wait for I-learn to recover its connection so that it can open a schedule for filling out the quiz. The failure of connection can also affect the mood of students in studying, who initially were excited to become lazy because of the difficulty of access to Ilearn. Regarding this, the information and technology unit in the university should increase their server capacity so that the learning process can run smoothly.
To measure student learning progress, lecturers provide quizzes every week. Quizzes conducted online using the features available in LMS. The average score of the students' quizzes in six meetings was 82.62 at the second meeting; then 92.50 at the third meeting; then 91.80 and 83.44 at meetings four and five; last 92.46 and 86.39 at meetings six and seven. The quiz scores show that students have a good understanding of the lecture material taught by the lecturer. Besides, the students' quiz scores per week were above 80 . These results indicate that the video delivered could be followed by students. Through this video, students can repeatedly hear explanations if there are things that are not understood. Also, during lectures, students actively ask questions related to materials, quizzes, and assignments given online.

Apart from quizzes, assigning assignments is also necessary considering the implementation of lectures that do not use face-to-face methods. When lectures use the face-to-face method, the interaction will be more comfortable, in the sense that after the instructor or lecturer has finished delivering the material directly, the instructor can also confirm whether the class participants pay attention or not.

However, this will be an obstacle when learning uses the online method, namely meetings that use learning videos for participants to watch. This phenomenon creates a dilemma because lecturers cannot confirm whether students have watched the video seriously and have absorbed the material contained in the video. To make sure, after the video uploaded, a few minutes later, the quiz is given. Usually, the distance between the video link notification and the quiz is 30 to 45 minutes. It aims to encourage students to immediately watch the uploaded video and pay attention because there will be a quiz afterward. The quiz is in the form of true or false toward a given question related to the material they have just watched. However, the time given is a concise and random question in order to reduce the possibility of cheating.

The quiz given is designed to make sure two things, first, to make sure students do not skip the video randomly and only to see the information on the slide without listening to detailed explanation through the audio in the video. They will have difficulty answering the quiz questions. Sometimes, the question deliberately ambiguous to train them thoroughly. The following is an example of a question "ICRC stands for International Committee of Red Crescent." It will trap students who ignore the video because even though the Powerpoint slide in the video clearly shows that ICRC stands for the International Committee of Red Cross, the instructor will then explain if ICRC is also short for the International Committee of Red Crescent. It means that not all critical information is shown on the Powerpoint slide in the video, but also through lecturer explanations. So, students who are not careful and do not watch the video properly will get caught up in the quiz question. Second, the question is also designed to 
elicit questions from students, such as "Why should there be different extensions for the ICRC?". This phenomenon shows that the lecturer able to build an atmosphere class by online learning. These student questions can generate discussion and encourage other class participants to participate in the discussion. Lecturer also provides sessions for group discussion related to the questions given in I- learn. Discussions are conducted by students via I-learn and also through social media platforms such as Whatsapp (WA). WA was chosen as a discussion forum because first, the condition of i-learn, which is difficult to access, and the connection is unstable, so alternatives needed if $i-$ learn cannot be accessed. If i-learn is having problems and the discussion process is still forced to continue in i-learn, it will have an impact on the dynamics of the discussion itself. The discussion does not run smoothly because the answers, responses, or questions from students or instructors disrupted due to the stability of i-learn access.

Second, WA is the social media that is most widely used by students compared to other instant messaging applications. So the accessibility of discussions using the WA platform will be very high. Goggle Classroom is not used based on student feedback on previous semester lectures as a medium for discussion. Although it has almost the same accessibility as WA, comments, or responses from students or instructors if written in the Google Classroom comments column rarely appear instantly without being referenced first. It is where WA has the advantage over Google Classroom.

For assignments submitted by students, there are not only traditional tasks, such as written assignments. In blended learning, the use of i-learn is more prioritized so that assignments will be collected via ilearn. By utilizing i- learn, it opens wider opportunities in the form of assignment submissions. The assignment can also be in audio form, so that not only can students' writing skills be seen, but how students elaborate on the information and knowledge they have acquired in a language that is easy to understand. The lecturer then gives questions which will then be answered by students with their analysis based on the understanding of the video and reading given. The answers are then recorded in audio form and then sent to i-learn for assessment.

To measure student satisfaction regarding the methods and media used, the student fulfilled a survey. From the survey, the majority of students $(95.8 \%)$ agreed that the delivery of material through video made it easier for students to understand the subject matter taught. These results indicate that the learning objectives contained in the learning plan are implemented well, even though they are done online. Then, the majority of class participants (97.6\%) also agreed that even though lectures were not conducted face-to-face, the use of instructional videos could foster student learning motivation. This is because the majority of student class participants $(81.3 \%)$ feel that if the lecturer does not explain the lecture material, the class participants find it difficult to follow the learning process that is carried out. In this student's opinion, it concluded that in the learning process, the lecturer must explain the lecture material studied as a form of introduction and direction for students before carrying out class activities in lectures. Besides, the majority of class participants $(95.8 \%)$ agree that the use of quizzes in lectures is excellent as a form of measuring student understanding of the lecture material described. Quiz results can also be useful for lecturers for future improvement.

Although students agree that online lectures using video make it easier to understand the material, related to the use of i-learn, only $38.1 \%$ of students who participate in the class agree to use i-learn in-class activities. This figure is relatively low because the majority of students participating in the class $(94.1 \%)$ experience problems with i-learn connections in-class activities. As a result, class activities such as group discussions conducted via i-learn were not significant, according to most students $(50 \%)$. To overcome this, the lecturers often use other platforms such as WAG (WhatsApp Group) which are more accessible to students so that class activities can continue.

Based on the survey conducted, it concluded that the practice of blended learning using instructional videos could be an option for lecturers in carrying out lectures. The reason is; first, learning videos are more efficient for students in using data packages because they can download. Second, the use of this video will make it easier for students to carry out independent learning because students can repeat the material presented by the lecturer. Third, the need for a measurement method for student understanding related to learning, such as giving quizzes. However, the obstacles that must be anticipated by the lecturer in implementing this method are; first, the error of the campus LMS server used. Second, the small capacity of data sizes that can be uploaded by students and lecturers in conducting online learning is also a difficulty. For students, the assignment files that can be uploaded are only $5 \mathrm{MB}$, while the lecturers are $20 \mathrm{MB}$. This size is small enough for today's lectures. Not infrequently, lecturers, and students end up using other platforms to upload materials or assignments whose capacity is larger than the size set in i-learn.

\section{CONCLUSION}

Based on the analysis conducted, it concluded that the use of the blended learning method in lectures could be a choice for lecturers that can increase student understanding and motivation. Especially in today's pandemic, which makes it difficult for lecturers to carry out lectures in class as usual. This lecture was conducted with the synchronous type, where students can access lectures anywhere at the same time. The 
lecturer requires instructions before lectures are carried out so that students can focus on learning. There are limitations to the limited data package by students, so the use of instructional videos is a good step in explaining lectures. Then after watching the video, students should be given a quiz as a way to measure students' understanding of the material studied. This blended learning method rests on a stable internet connection network and a stable Learning Management System (LMS) server as a place for conducting online lectures. However, based on the survey results, students had problems accessing the LMS because the servers were often down. The impact is it difficult for students to carry out class activities that support the achievement of learning outcomes.

Blended Learning also opens up various possibilities for learning methods that are more flexible, even if they tend to be more interactive. It goes back to how the execution in carrying out Blended Learning learning. For example, the use of quizzes which can encourage students to pay more attention to video material and provoke discussion. The sense of collecting assignments that is not only focused on written assignments but also in the form of assignments, where answers to these assignments made to show student understanding in other forms, for example submitting assignments in audio form will show students' ability to explain their understanding of the material through oral delivery.

\section{ACKNOWLEDGMENT}

This paper is supported by the Institute for Educational Development and Quality Assurance of Andalas University through the Blended Learning Development Grant Fund provided by Andalas University in 2020.

\section{REFERENCES}

[1] R. Raja and P. C. Nagasubramani, Impact of Modern Technology in Education, Journal of Applied and Advanced Research, 2018: 3 (Suppl.1) S33-S35.

DOI: https://dx.doi.org/10.21839/jaar.2018.v3S1.165

[2] A. Procter Heinze and B. Scott, Use of Conversation theory to underpin Blended Learning, International Journal of Teaching and Case Studies, Vol. 1, No. 1, 2007, PP. 108-120

[3] J. Carman, Blended Learning Design: Five Key Ingredients, August 2002, pp. 1-10

[4] D. Curtis and M. Lawson, Exploring Collaborative Online Learning, Journal Asynchronous Learning Networks, Vol. 5, No. 1, pp.21-34

[5] Singh, H. (2003). Building effective blended learning programs. Educational Technology-Saddle Brook Then Englewood Cliffs NJ-, 43(6), 51-54.
[6] Sudarman, Pengaruh Strategi Pembelajaran Blended Learning Terhadap Perolehan Belajar Konsep dan Prosedur pada Mahasiswa yang Memiliki Self Regulated Learning Berbeda, Jurnal Pendidikan dan Pembelajaran, Vol. 21, No. 1, April 2014, pp. $107-$ 117.

[7] N. Jones, The Disruptive Effect of Technology: a University Case Study, in Proceeding of the Workshop on Blended Learning, 2007, pp. 114122C. 